\title{
НОВЫЕ ГИДРАЗОНЫ ПРОИЗВОДНЫЕ ТРИПТАНТРИНА
}

\author{
А.Г. Васин ${ }^{1,2}$, А.Е. Щекотихин ${ }^{1}$ \\ ${ }^{1}$ Научно-исследовательский институт по изысканию новых антибиотиков \\ им. Г. Ф. Гаузе, 119021, Россия, Москва, ул. Большая Пироговская, д. 11, стр. 1. \\ 2Российский химико-технологический университет им. Д. И. Менделеева, \\ 125190, Россия, Москва, Миусская пл., д. 9.
}

DOI: 10.19163/MedChemRussia2021-2021-306

E-mail: andreyvasinh@gmail.com

В связи с постоянным ростом распространенности резистентных штаммов возбудителей инфекционных заболеваний поиск новых противомикробных средств остается важной задачей медицинской химии. Большинство используемых сегодня в клинике антибиотиков, создано на основе биологически активных соединений природного происхождения. Высоким потенциалом для поиска новых полусинтетических препаратов обладает алкалоид триптантрин. Согласно данным литературы, триптантрин и его производные имеют широкий спектр биологической активности, в частности антигрибковую, антипролиферативную и антимикробную [1].

Перспективным направлением модификации триптантрина является синтез его гидразонов $[1,2]$. Серия новых производных триптантрина 5a-c получена с высоким выходом путем конденсации алкалоида 3 и гидразидов гетероциклических карбоновых кислот 4а-с (никотиновой, изоникотиновой, пиразин-2-карбоновой), обладающих высокой противотуберкулезной активностью. Исходный триптантрин был получен по описанной методике [3].<smiles>O=C1Nc2ccccc2C1=O</smiles>

1<smiles>CCN(CC)CCN1Nc2ccccc2C(=O)OC1=O</smiles>

$89 \%$<smiles>O=C1c2ccccc2-n2c1nc1ccccc1c2=O</smiles>

3<smiles>[R][C+]=CC=C(C)C=N</smiles>

$4 a$<smiles>[R]C(=O)NN</smiles><smiles>Cc1ccncc1</smiles>

$4 \mathrm{~b}$<smiles>N/N=C1/c2ccccc2-n2c1nc1ccccc1c2=O</smiles><smiles></smiles>

В настоящее время проводится сравнительное исследование биологических свойств триптантрина и его гидразонов.

\section{Литература}

[1] Kaur R. et al. Bioorganic \& medicinal chemistry, 2017, 25, 17, 4533-4552.

[2] Krivogorsky B. et al. Bioorganic \& medicinal chemistry letters, 23, 4, 1032-1035

[3] Yang S. et al. Journal of Medicinal Chemistry, 56, 21, 8321-8331

$$
-306-
$$

